九州大学学術情報リポジトリ

Kyushu University Institutional Repository

\title{
Variation of Glucosephosphate Isomerase and Phosphoglucomutase Isozymes in Vitis and Their use in Grape Breeding
}

Shiraishi, Shinichi

Fruit Science Laboratory, Faculty of Agriculture, Kyushu University

Ohmi, Chie

Fruit Science Laboratory, Faculty of Agriculture, Kyushu University

Wakana, Akira

Fruit Science Laboratory, Faculty of Agriculture, Kyushu University

Hiramatsu, Michikazu

Fruit Science Laboratory, Faculty of Agriculture, Kyushu University

https://doi.org/10.5109/24057

出版情報 : 九州大学大学院農学研究院紀要. 38 (3/4)，pp. 255-272，1994-03. Kyushu University バージョン：

権利関係 : 


\title{
Variation of Glucosephosphate Isomerase and Phosphoglucomutase I sozymes in Vitis and Their use in Grape Breeding
}

\author{
Shiiiichi Shiraishi, Chie Ohmi, Akira Wakana and Michikazu Hiramatsu
}

Fruit Science Laboratory, Faculty of Agriculture, Kyushu University Fukuoka 812 - 23, Japan

(Received January. 17, 1994)

\begin{abstract}
Inheritance and variation of glucosephosphate isomerase (GPI) and phosphoglu comutase (PGM) isozymes in Vitis and their usefulness in triploid grape breeding were investigated using horizontal starch gel electrophoresis. No isozyme variations were observed within cultivars. On electrophoretic analysis of 99 diploid cultivars, 20 diploid plants from 8 wild species, and their progenies, thirteen alleles were found for $G p i-2$ and eleven for Pgm-2. The data indicate high degree of genetic divergence between species in Vitis. Subsequently, genotypes for Gpi-2 and Pgm -2 were determined in 6 diploid cultivars and 4 tetraploid cultivars used for crossings. Of 98 seedlings from 15 controlled crosses between the diploid and tetraploid cultivars, 92 exhibiting trisomic gene expression could be determined to be triploid hybrids, while 6 exhibiting disomic gene expression were determined to be diploid plants produced by contaminating pollen. These results indicate that the two highly variable enzyme systems are very useful for breeding and phylogenetic study in grape.
\end{abstract}

\section{INTRODUCTION}

The grape is not a convenient plant for genetic analysis because of its long life cycle (about 3 years), large number of chromosomes $(2 \mathrm{n}=2 \mathrm{x}=38)$, partial sterility of embryo sacs and low seed germination (Einset and Pratt, 1975). Hence, the inheritance of specific characteristics has been worked out for a few characteristics such as fruit color (Baritt and Einset, 1969), disease resistance (Mortensen, 1968) and stenospermocarpy (Stout, 1939), but few of the genes are of any real value to breeder as genetic markers in grape.

Isozyme electrophoresis provides us a new technique to demonstrate marker genes in grape in which a large number of isozyme polymorphisms have been described (Wolfe, 1976; Schwennesen et al., 1982; Stavrakakis and Loukas, 1983; Subden et al., 1987; Goldy et al., 1988; Chaparro et al., 1989; Durham et al., 1989; Goldy et al., 1989; Walters et al., 1989; Gray et al., 1990). A large number of polymorphic isozyme loci have been identified in grape (Loukas et al., 1983; Weeden et al., 1988). Genetic analysis of these polymorphic isozyme systems confirmed that grape cultivars are highly heterozygous, and supported the hypothesis that the ancestors of modern grape cultivars were diploidized polyploid with an outcrossing system (Olmo, 1976).

Glucosephosphate isomerase (GPI; EC 5.3.1.9.) and phosphoglucomutase (PGM; EC 2.7.5.1.), the most widely studied enzymes in plants, are known to be polymorphic in many genera and their isozyme loci have been identified (Gottlieb, 1982; Weeden and Wendel, 1989). In grape, polymorphism of GPI was firstly shown by Stavrakakis and Loukas (1983) and two isozymes, a plastidspecific isozyme GPI - 1 and a cytosolic isozyme GPI - 2, have been identified by Weeden et al. (1988). Polymorphism of PGM 
was firstly shown also by Stavrakakis and Loukas (1983) and a plastid -specific isozyme PGM-1 and a cytosolic isozyme PGM-2 have been identified by Weeden et $a l$. (1988). On the basis of banding phenotypes in 145 grape cultivars and results of progeny tests, Parfitt and Arulsekar (1989) described two isozyme loci, Gpi-2 and Pgm2 , with at least $4(\mathrm{a}, \mathrm{b}, \mathrm{c}, \mathrm{d})$ and $3(\mathrm{a}, \mathrm{b}, \mathrm{c})$ alleles respectively.

Further data on the genetic basis of polymorphism for the two enzymes in grape and successful screening of seedling progenies for triploid hybrids between diploid and tetraploid cultivars are reported in this paper.

\section{MATERIALS AND METHODS}

\section{Plant Material}

Sixty-two Vitis vinifera cultivars, 33 interspecific hybrid cultivars, 4 cultivars from 3 American species and 20 individuals from 8 with species of Vitis were sampled (Table 1). Shoot apices from all the cultivars and wild species were obtained from plants grown in 3 vineyards; Fukuoka Agricultural Research Center, Fukuoka; University Farm of Kyushu University, Fukuoka; Akitsu Branch, Fruit Tree Research Station, Hiroshima.

Seedlings from 5 progenies from 5 controlled crosses were planted in 1986, 1989 and 1990, and were examined in the spring of 1989 and 1990. Of 9 cultivars used in the 5 crosses, 'Alicante - Bouschet', 'Chasselas Rose', 'Flame Tokay', 'Queen' and 'Thompson Seedless' are $V$. vinifera cultivars, 'Russky Concord has $V$. labrusca and $V$. amurensis in its parentage, 'Schuyler' has $V$. vinifera, $V$. labrusca and $V$. amurensis in its parentage, and 'Muscat Bailey A' has $V$. vinifera, $V$. labrusca and $V$. lincecumii in its pedigree.

To produce selfed seeds for genetic analysis in the endosperm, 'Mills', which has $V$. vinifera and V. labrusca in its parentage, was bagged in 1990 and the endosperm was examined in the winter of 1990.

In order to produce triploid hybrids, 6 diploid cultivars, 'Delaware', 'Muscat Bailey A', 'Muscat of Alexandria', 'Neo Muscat', 'Rizamat' and 'Sekirei', and 4 tetraploid cultivars, 'Cannon Hall Muscat', 'Kyoho', 'Red Pearl' and 'Yufu' were used. 'Muscat of Alexandria', 'Rizamat' and 'Connon Hall Muscat' are $V$. vinifera cultivars. 'Delaware' has $V$. vinifera, $V$. labrusca and $V$. aestivalis var. bourquiniana in its parentage. 'Kyoho' has $V$. vinifera and $V$. labrusca in its parentage. 'Neo Muscat' and 'Sekirei' have $V$. vinifera and uncertain Vitis species in their parentage. 'Red Pearl' and 'Yufu' are sports of 'Delaware' and 'Muscat Bailey A' respectively. Fifteen crosses between the diploid and tetraploid cultivars were made from 1985 to 1989. A few days before anthesis, flowers were emasculated carefully, sprayed with water to prevent self -pollination and bagged to avoid outcrossing. Hand-pollination was made at a full bloom stage and bagged again. The seedlings from the 15 progenies were obtained through embryo culture in 1988 and 1989 and by sowing in the other years, and were examined in the summer of 1990. The embryo culture was made at a ripening stage of berry growth on the basal MS medium (Murashige and Skoog, 1962) supplemented with either $100 \mathrm{mg} / 1$ casamino acid or $250 \mathrm{mg} / 1$ malt extract. 
Table 1. Vitis cultivars analyzed.

\begin{tabular}{|c|c|}
\hline $\begin{array}{l}\text { Species and } \\
\text { interspecific } \\
\text { hybrid }\end{array}$ & Cultivar \\
\hline $\begin{array}{c}\text { European speci } \\
\text { v. vinifera }\end{array}$ & $\begin{array}{l}\text { Acma, Aleksandrouli, Alicante-Bouschet, } \\
\text { Anab-e-shahi, Avasirhva, Baijixin Baladi, } \\
\text { Black Hamburg, Chasselas Rose, Chenin Blanc, } \\
\text { Citronelle, Dattier de Beyrouth, Dayuylu, } \\
\text { Emperor, Flame Tokay, French Colombard, } \\
\text { Heijixin, Hongniuai, Huangkalasi, huotiahong, } \\
\text { Hussiene, Iracema, Italia, Itchkimar, } \\
\text { July Muscat, Kali Sahebi, Kandahar, } \\
\text { Katta Kurgan, Kizliarskij cernyj, } \\
\text { Königin der Weingarten, Krimskij, Lunai, } \\
\text { Madeleine Angevine, Malbec, Mission, Monukka, } \\
\text { Muscat Hamburg, Muscat of Alexandria, } \\
\text { Muscat Uzbecistansij, Nehelescol, Nimrang, } \\
\text { Niuai, Pannoniakincse, Parkent, Puhljakovskij, } \\
\text { Pusa Seedlees, Queen, Red Ohanez, Rich Baba, } \\
\text { Rizamat, Rose d'Italia, Ruby Cabernet, } \\
\text { Ruby Seedless, Ryugan, Soiaki, Tagobi, Taifei, } \\
\text { Taifi Rozovij, Tavriz, Thompson Seedless, } \\
\text { Volga Don, Zhana }\end{array}$ \\
\hline $\begin{array}{c}\text { American spec } \\
\text { V. champini } \\
\text { V. labrusca } \\
\text { V. rupestris } \\
\text { Interspecific }\end{array}$ & $\begin{array}{l}\text { Salt Creek } \\
\text { Concord, Fredonia } \\
\text { St. George } \\
\text { een European and American species } \\
\text { Bronx Seedless, Buffalo, Campbell Early, } \\
\text { Canadice, Couderc 1202, Delaware, Diana, } \\
\text { Empire State, Fuefuki, Glenora, Golden Muscat, } \\
\text { Hanover, Headlight, Hybrid Franc, Iona, } \\
\text { Jessica, Mills, Muscat Bailey A, New Niagara, } \\
\text { New York Muscat, Niagara, Ontario, Patricia, } \\
\text { Pierce, Scarlet, Schuyler, Seneca, Settsu, } \\
\text { Sheridan, Steuben, Super Hamburg, Wayne, Yates }\end{array}$ \\
\hline
\end{tabular}

\section{Sample preparation and enzyme extraction}

In addition to shoot apices, fully expanded young and mature leaves, young and mature twigs, young roots, pollen and endosperms were used for enzyme extraction. The sporophytic tissues were collected in plastic bags to maintain a humid environment and examined immediately or stored in the dark for 1 to 7 days at $5^{\circ} \mathrm{C}$ until use. Pollen was collected on a plate glass at anthesis by tapping at the bloom cluster, and examined immediately or stored in the dark for 1 to 4 weeks at $5^{\circ} \mathrm{C}$ until use. Approximately $0.2 \mathrm{~g}$ of the sporophytic tissues, $0.005 \mathrm{~g}$ of the pollen and endosperms were respectively homogenized by hand in a pre - chilled mortar and with a pestle with $1.0 \mathrm{ml}$ for sporophytic tissue and $0.5 \mathrm{ml}$ for pollen and endosperms of chilled extraction 
buffer prepared as described by Wendel and Parks (1982) except that 5\% PVP K-30 (Nacalai Tesque, Inc. Kyoto) was added instead of 5\% PVP-40. Crude enzyme extracts obtained from this procedure were absorbed onto filter paper wicks (Whatman \# 3, 11 $\mathrm{X} 3 \mathrm{~mm}$ ) and used for electrophoresis. All extractions were performed at room temperature $\left(10-20^{\circ} \mathrm{C}\right)$.

\section{E lectrophoresis and enzyme detection}

Horizontal starch gel electrophoresis was conducted using a tris/ citrate buffer system as described by Wendel and Parks (1982), except that $32.40 \mathrm{~g}$ Starch-hydrolyzed (Nacalai Tesque, Inc. Kyoto, Japan) was used instead of $32.40 \mathrm{~g}$ electrostarch. The wicks absorbing sample extracts were vertically inserted into pre - cooled gel. Electrophoresis was carried out at $2-4^{\circ} \mathrm{C}$ for 8 hours at 10 watts. After electrophoresis, the anodal section of the gel was sliced horizontally into $\mathrm{lmm}$ thick slices and stained for two enzyme systems, GPI and PGM. Staining of GPI and PGM followed Wendel and Parks (1982).

\section{Allozyme nomenclature}

According to the International Union of Biochemistry (Webb, 1984), the locus coding for the products with the most anodal mobility was designated as 1 , the next 2 , and so forth. Similarly, at each locus, the allele coding for the most anodal or the fastest migrating allozyme was given the alphabetical code $a$, next $b$, and so on.

\section{Chromosome observation}

To examine the ploidy level of 'Red Pearl', 'Yufu' and seedlings obtained from the 15 crosses between diploid and tetraploid cultivars, root tips obtained from their cuttings were pre - treated with $0.002 \mathrm{M} 8$ - hydroxyquinoline for 24 hours at $10^{\circ} \mathrm{C}$, dehydrolyzed in a solution of $1 \mathrm{~N} \mathrm{HCl}$ and $45 \%$ acetic acid (1:1) for 1 minute at $60^{\circ} \mathrm{C}$, stained with lactic propionic orcein (Dyer, 1963) for 24 hours at room temperature, squashed under a glass cover, and observed with a microscope.

\section{RESULTS}

Two enzyme systems from protein extracts from various tissues of grape cultivars and wild Vitis species could be resolved by starch gel electrophoresis. They were polymorphic and exhibited allelic variation at one or two enzyme loci.

First, results will deal with GPI extracted from diploid cultivars and wild species $(2 n=2 x=38)$. Two anodal zones of enzyme activity were detected in all tissues studied. The fast migrating zone GPI-1 was invariant for a single and relatively wide band migrating $9 \mathrm{~cm}$ form the origin on the gel in all species and cultivars surveyed. When the sporophytic tissues were examined, the slow migrating zone GPI - 2 was variant and exhibited either a single - or three - banded pattern (Fig. 1). The intermediate band of the three bands was stained denser than the other two bands, and was not appeared on the gel when a crashed pollen extract of the same cultivar was used. When triploid endosperms were examined, the slow migrating zone GPI - 2 exhibited either a one-or three - banded pattern. The three-banded pattern was 


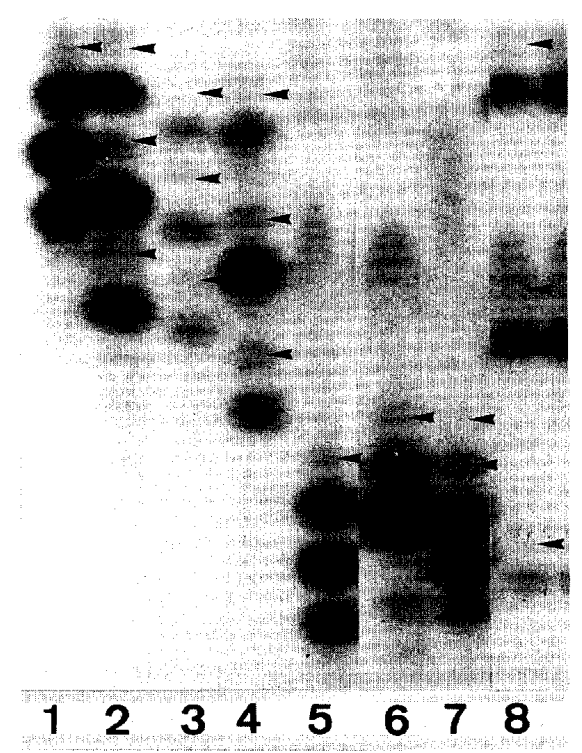

Fig. 1. GPI zymograms of diploid cultivars. 1. 'Jessica'; 2. 'Alicante Bouschet'; 3. 'Mills'; 4. 'Russky Concord'; 5. 'Empire State'; 6. 'St. George'; 7. 'Salt Creek'; 8. 'Delaware'. The arrows indicate ghost bands. Anode is toward the top of the figure.

separated into two types which could be distinguished by their relative intensities of the fast and slow bands. These are the banding patterns typical for a dimeric enzyme as has been reported in grape (Weeden et al., 1988; Parfitt and Arulsekar, 1989) and all other plants examined (e.g., Torres et al., 1978; Weeden and Gottlieb, 1979; Gottlieb, 1982; Wendel and Parks, 1983; Goldring et al., 1985; Parfitt et al., 1985; Chevreau and Leurens, 1987; Pedersen et al., 1987; Suiter, 1988).

In the zymograms of all samples analyzed, each of the bands often appeared with more than one faint bands migrating anodally to the bands with intervals of about $5 \mathrm{~mm}$ (Fig. 1). Intensity of the faint bands decreased as they migrated from the bands. The extent of intensity of the faint bands was different in different tissues examined; i.e., the occurrence of the faint bands was conspicuous in extracts from mature twigs and fully expanded leaves, but no or a little trace of the faint bands was detected on the gel when pollen, endosperms. very young leaves and shoot apices were used as enzyme sources. These results indicate that the faint bands are break-down products of the isozymes and are negligible for genetic analysis and that the usage of extracts from young tissues provides us consistent zymograms to analyze the isozyme variation in grape.

Ninety-nine diploid cultivars and 20 plants from 8 wild Vitis species were analyzed electrophoretically and divided into 31 banding phenotypes for Gpi-2. The mobilities of 13 homodimeric allozymes of GPI found in this study were listed in Fig. 2 with their corresponding hypothetic alleles at Gpi-2. Segregation analysis confirmed that $\mathbf{G} \mathbf{p i - 2}$ is an isozyme governed by a single locus $G p i-2$ (Table 2). The segregation patterns in $\mathrm{F}_{1}$ progenies and endosperm did not significantly deviated from the expected ratio at $5 \%$ 


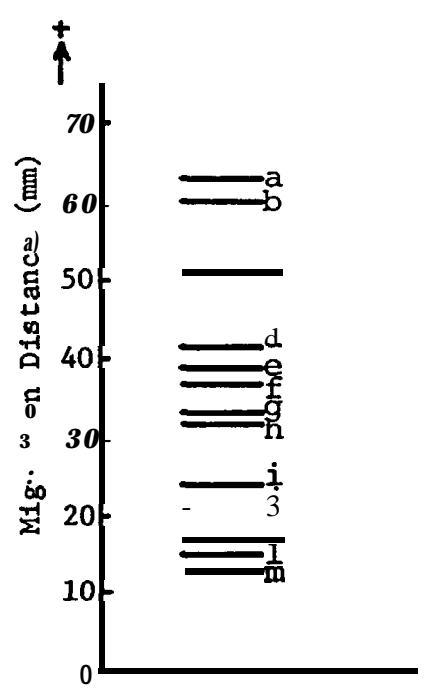

Fig. 2. Position of homodimetric allozymes of Gpi-2. Anode is toward the top of the figure.

Table 2. Goodness-of-fit tests for single locus segregation patterns at Gpi-2.

Cross
Prospected parental
Gpi -2 genotypes

ad $\times$ bb $24 \mathrm{ab}: 34 \mathrm{bda}$ ad $\times$ bi $10 \mathrm{ab}: 11 \mathrm{ai}: 11 \mathrm{bd}: 17 \mathrm{di}^{\mathrm{a}}$ aa $\times$ bi $24 \mathrm{ab}: 34 \mathrm{ai}^{\mathrm{a}}$ aa $\times$ ad $25 \mathrm{aa}: 28 \mathrm{ad}^{\mathrm{a}}$

A aj Xaj 25aa:44aj : 20jj

aj X bg 20ab : 24ag : 16bj : 23gj ${ }^{\mathrm{a}}$ be $\times$ be $12 \mathrm{bbb}: 15$ bbe : 13bee :10eee ${ }^{\mathrm{b}} 1: 1: 1: 1 \quad 1.04 \quad 0.800-0.700$ $X^{2} \quad \mathbf{P}$

$\begin{array}{lll}1: 1 & 1.72 & 0.200-0.100\end{array}$

$1: 1: 1: 1 \quad 2.51 \quad 0.500-0.300$

$1: 1 \quad 1.72 \quad 0.200-0.100$

$\begin{array}{lll}1: 1 & 0.17 \quad 0.700-0.500\end{array}$

$\begin{array}{lll}1: 2: 1 \quad 0.57 & 0.800-0.700\end{array}$

$\begin{array}{lll}1: 1: 1: 1 & 1.87 & 0.700-0.500\end{array}$
Alicante-Bouschet X Flame Tokay

Alicante-Bouschet X Schuyler

Queen X Thompson Seedless

Muscat Bailey $A \times$ Muscat Bailey A

Muscat Bailey A X Russky Concord

Mills X Mills
Progeny and endosperm
genotypes ratio

a, Progeny; b, Endosperm.

level in all the cross combinations. This indicated that in the diploid sporophytic tissues and triploid endosperms the single-banded and three -banded patterns reflect homozygosity and heterozygosity at Gpi-2 respectively and that at least 13 alleles exist at Gpi-2 in Vitis. Of the 13 alleles detected, 4 alleles were found in V.vinifera, 6 alleles in 4 American Vitis species and 5 alleles in 5 East Asian Vitis species, and 9 alleles in American hybrid cultivars (Table 3). On comparing species on different continents, 3 alleles, a, b and h, were exclusively found in $\mathbf{V}$. vinifera, 5 alleles, e, i, k, 1 and $\mathrm{m}$, in American species, and 2 alleles, $f$ and g, in East Asian species.

Second, results will deal with PGM extracted from the diploid cultivars and wild species. Two anodal zones of enzyme activity were detected in all samples analyzed. No differences of banding patterns were detected between the sporophytic tissues of the same cultivar. The fast migrating zone PGM- 1 was variant for 3 to 5 indistinctive bands. The slow migrating zone PGM-2 exhibited either a single -or two-banded pattern (Fig. 3). No differences of banding patterns were seen between sporophytic 
Table 3. Alleles of Gpi-2 and Pgm-2 found in species and interspecific hybrids in Vitis.

\begin{tabular}{|c|c|c|c|}
\hline \multirow{2}{*}{$\begin{array}{l}\text { Species and } \\
\text { interspecific } \\
\text { hybrid }\end{array}$} & \multirow{2}{*}{$\begin{array}{l}\text { No. of cultivars } \\
\text { and individuals } \\
\text { analysed }\end{array}$} & \multicolumn{2}{|c|}{ Allele } \\
\hline & & $G p i-2$ & Pmg-2 \\
\hline \multicolumn{4}{|l|}{ European species } \\
\hline V. vinifera & 62 & abdh & bdehi \\
\hline \multicolumn{4}{|l|}{ North American species } \\
\hline V. labrusca & 3 & ceij & $\mathrm{gh}$ \\
\hline V. champini & 1 & $\mathrm{ji}$ & hk \\
\hline v. repestris & 2 & $\mathrm{j}$ & $\mathrm{h}$ \\
\hline V. vulpina & 1 & $\mathrm{jm}$ & hj \\
\hline \multicolumn{4}{|l|}{ East Asian species } \\
\hline V. amurensis & 1 & $\mathrm{~g}$ & c \\
\hline$V$. coignetiae & 2 & $\mathrm{j}$ & $\mathrm{ch}$ \\
\hline V. kiusiana & 1 & $\mathrm{~g}$ & c \\
\hline V. shiragai & 3 & $\mathrm{dfj}$ & ace \\
\hline V. thunbergii & 10 & cdfgj & ceh \\
\hline \multicolumn{4}{|l|}{ Intercontinental hybrids } \\
\hline American hybrids" & 33 & abcdeijkm & befghij \\
\hline
\end{tabular}

a. Interspecific hybrid cultivars with V. vinifera and North American species in their pedigree.

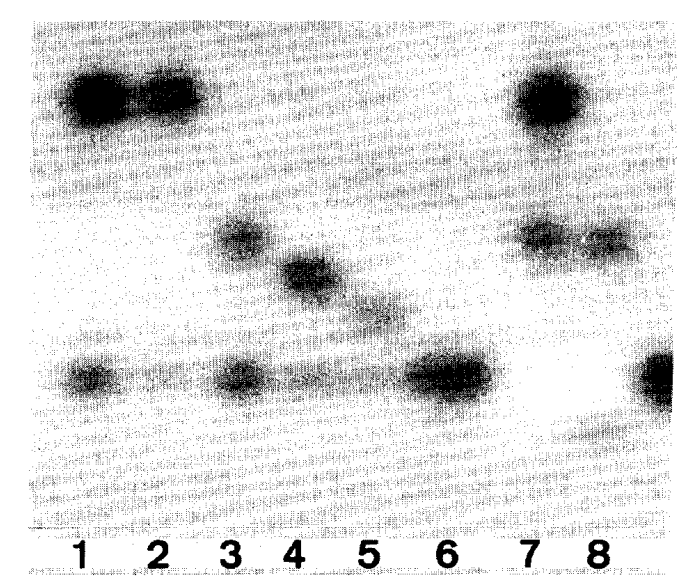

Fig. 3. PGM zymogram of diploid cultivars. 1. 'Wayne'; 2. 'Diana'; 3. 'Jessica'; 4. 'Dr. Collier'; 5. 'Portland'; 6. 'Schuyler'; 7. 'Malbec'; 8. 'Scarlet'. Anode is toward the top of the figure.

tissues and pollen of the same cultivars. When triploid endosperms were examined, PGM-2 exhibited either a single- or two-banded pattern. The two-banded pattern was separated into two types in which staining intensity was very different between the two bands. These were the banding patterns typical for a monomeric enzyme as has been reported in grape (Weeden et al., 1988) and all other plants analyzed (e.g., Wendel and 


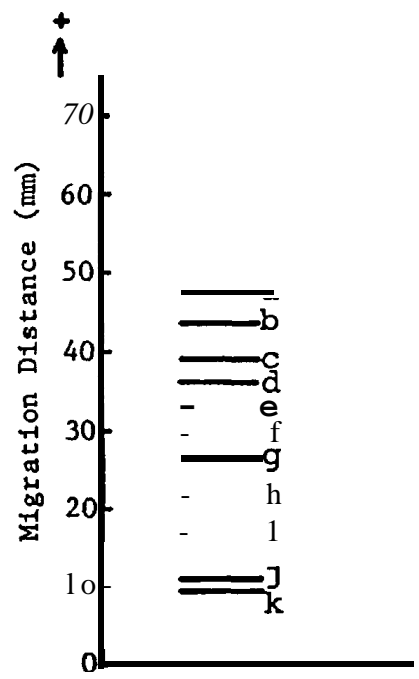

Fig. 4. Position of monomeric allozymes of Pgm-2. Anode is toward the top of the figure.

Table 4. Goodness-of-fit tests for single locus segregation patterns at Pgm-2.

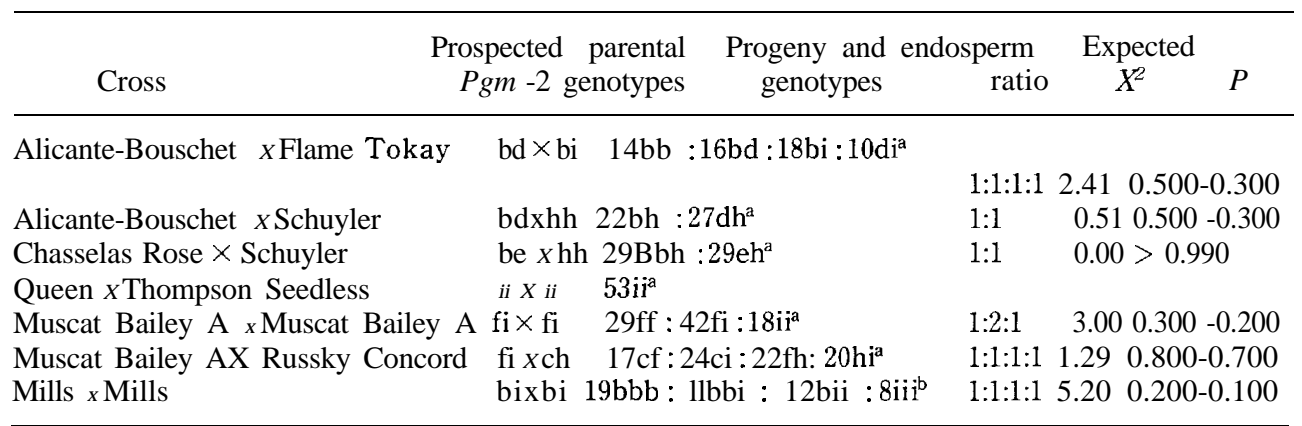

a, Progeny; b, Endosperm.

parks, 1982; Arus and Orton, 1984; Kahler and Lay, 1985; Suiter, 1988).

The diploid cultivars analyzed were divided into 21 banding phenotypes for PGM2. The mobilities of 11 monomeric allozymes of PGM found in this study were listed in Fig. 4 with their corresponding hypothetic alleles at Pgm-2 The segregation test in $\mathrm{F}_{1}$ progenies and endosperms (Table 4) confirmed that the allozymes of PGM-2 were governed by a second locus Pgm -2 as suggested by Weeden et al. (1988). Of the 11 alleles detected, 5 alleles were found in $V$. vinifera, 4 alleles in North American species, 4 alleles in East Asian species, and 7 alleles in American hybrids (Table 3). On comparing species on different continents, 3 alleles, $b, \mathrm{~d}$ and $\mathrm{i}$, were uniquely found in $V$.vinifera, 4 alleles, $\mathrm{f}, \mathrm{g}, \mathrm{j}$ and $\mathrm{k}$, in North American species, and 2 alleles, a and $\mathrm{c}$, in East Asian species.

The analysis of linkage relationships confirmed that the 2 enzyme loci Gpi-2 and 


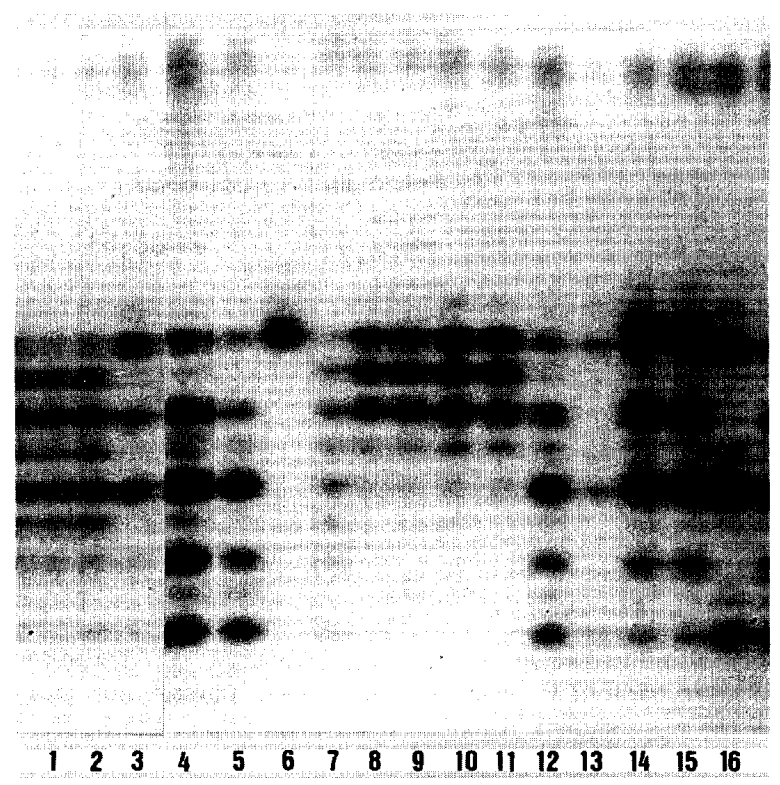

Fig. 5. GPI zymogram of tetraploid cultivars. 1. 'Kyoho'; 2. 'Takasumi'; 3. 'Hakuho'; 4. 'Olympia'; 5. 'Red Queen'; 6. 'Cannon Hall Muscat'; 7. 'Kuroshio'; 8. 'Pioné'; 9. 'Kaiakane'; 10. 'Izunishiki'; 11. 'Beniyamabico'; 12. 'Jasmine'; 13. 'Benifuji'; 14. 'Beniizu'; 15. 'Ryuho'; 16. 'Benizuiho'. Anodo is toward the top of figure.

Pgm-2 segregated independent of each other as indicated by Weeden et al. (1988) and Parfitt and Arulsekar (1989). With the combination of Gpi-2 and Pgm -2 genotypes, diploid cultivars and wild species were separated into 82 groups of which 59 groups consisted of only one cultivar or wild species. The genotype of each cultivar and wild species examined will be published elsewhere.

Third, a similar analysis was performed to determine the Gpi-2 genotypes responsible for one-to eight-banded patterns which were encountered in 4 tetraploid cultivars (Fig. 5) and 98 seedlings obtained from crosses between the 4 tetraploid cultivars and 6 diploid cultivars. In the tetraploid cultivars, one-, six-and ten- banded patterns must reflect nulliplex, trigenic and tetragenic genotypes respectively, while three banded patterns must reflect simplex or duplex genotypes. In the triploid progenies, one -, three- and six -banded patterns must reflect nulliplex, simplex and trigenic genotypes respectively. The results of GPI isozyme analysis of two triploid hybrids between diploid 'Muscat of Alexandria' with bb genotype for Gpi-2 and tetraploid 'Kyoho' exhibiting an eight -banded phenotype on the gel demonstrated the possibility (Fig. 6). The zymogram of one of the two triploid seedlings exhibited a three-banded phenotype reflecting simplex, while that of the another seedling exhibited a five-banded phenotype. The mobilities of allozyme bands and gene dosage confirm that the five-banded phenotype reflects a trigenic genotype; i.e., overlap of an homodimer band dd and heterodimer band bi on the gel resulted in the five-banded phenotype. Hence, the simplex and trigenic genotypes in the two triploid seedlings 


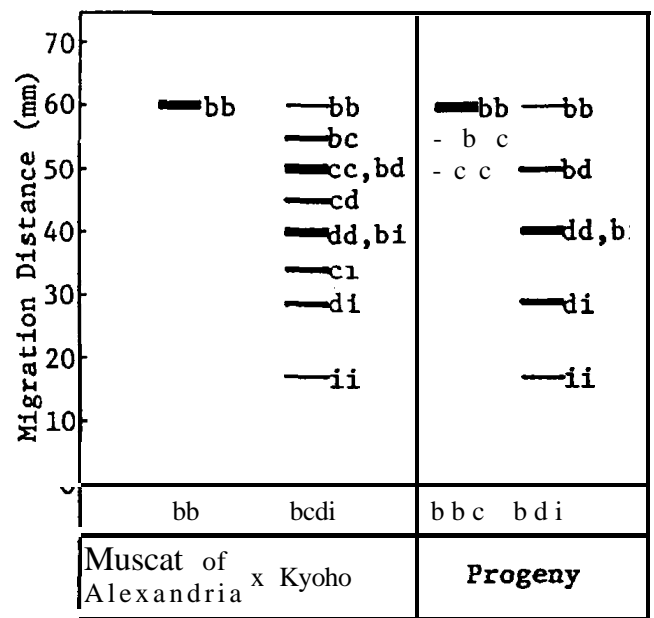

Fig. 6. Schematic illustration of allozymes in 'Muscat of Alexandria', 'Kyoho' and their triploid $F_{1}$ progeny for Gpi $=2$. Phenotypes and genotypes (below) were shown. Anode is toward the top of the figure.

were determined to be bbc and bdi, respectively. Consequently, genotype of 'Kyoho' exhibiting the eight-banded phenotype was confirmed bcdi. In this tetragenic genotype association of subunits coded by $G p i-2$ yielded ten bands but overlap of the heterodimer band bd and homodimer band $\mathrm{cc}$ and that of the heterodimer band bi and homodimer band dd on the gel resulted in the eight-banded pattern.

Not only zymograms of GPI extracts from the sporophytic tissues but those from the pollen also made it possible to confirm duplex genotypes in tetraploid cultivars by the consistent occurrence of the three bands and the consistent relative intensity of the respective allozyme band on the gel. A leaf extract from 'Yufu', a sport of 'Muscat Bailey A' with aj genotype for Gpi-2, and that from 'Red Pearl', a sport of 'Delaware' with ak genotype for Gpi-2, exhibited the same three-banded pattern as those from 'Muscat Bailey A' and 'Delaware' respectively, whereas zymograms of pollen extracts from the two tetraploid cultivars also exhibited the same three-banded pattern as those of their leaf extracts. Hence, 'Yufu' and 'Red Pearl' are tetraploid with aajj and aakk

Table 5. Gpi-2/Pgm-2 genotypes of the seedlings obttained from crosses between tetraploid and diploid cultivars.

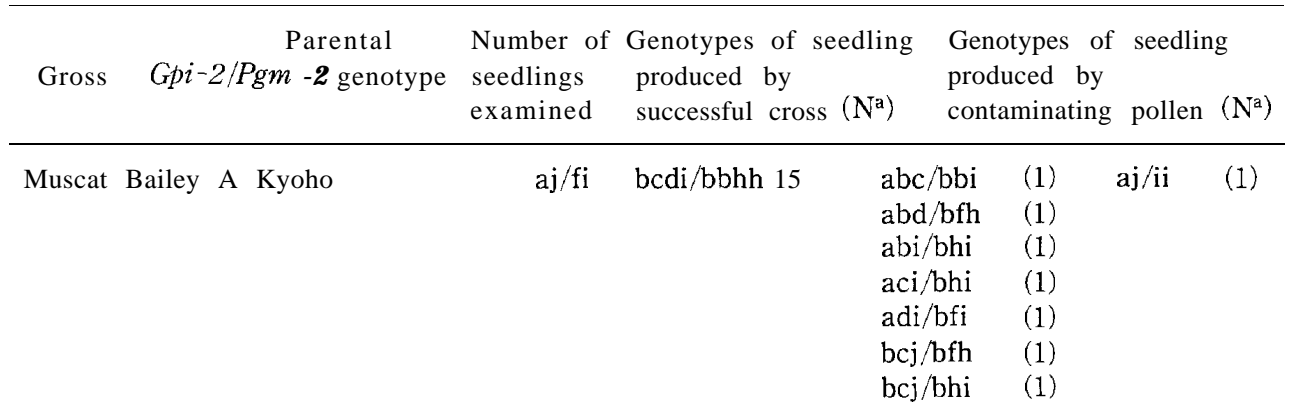




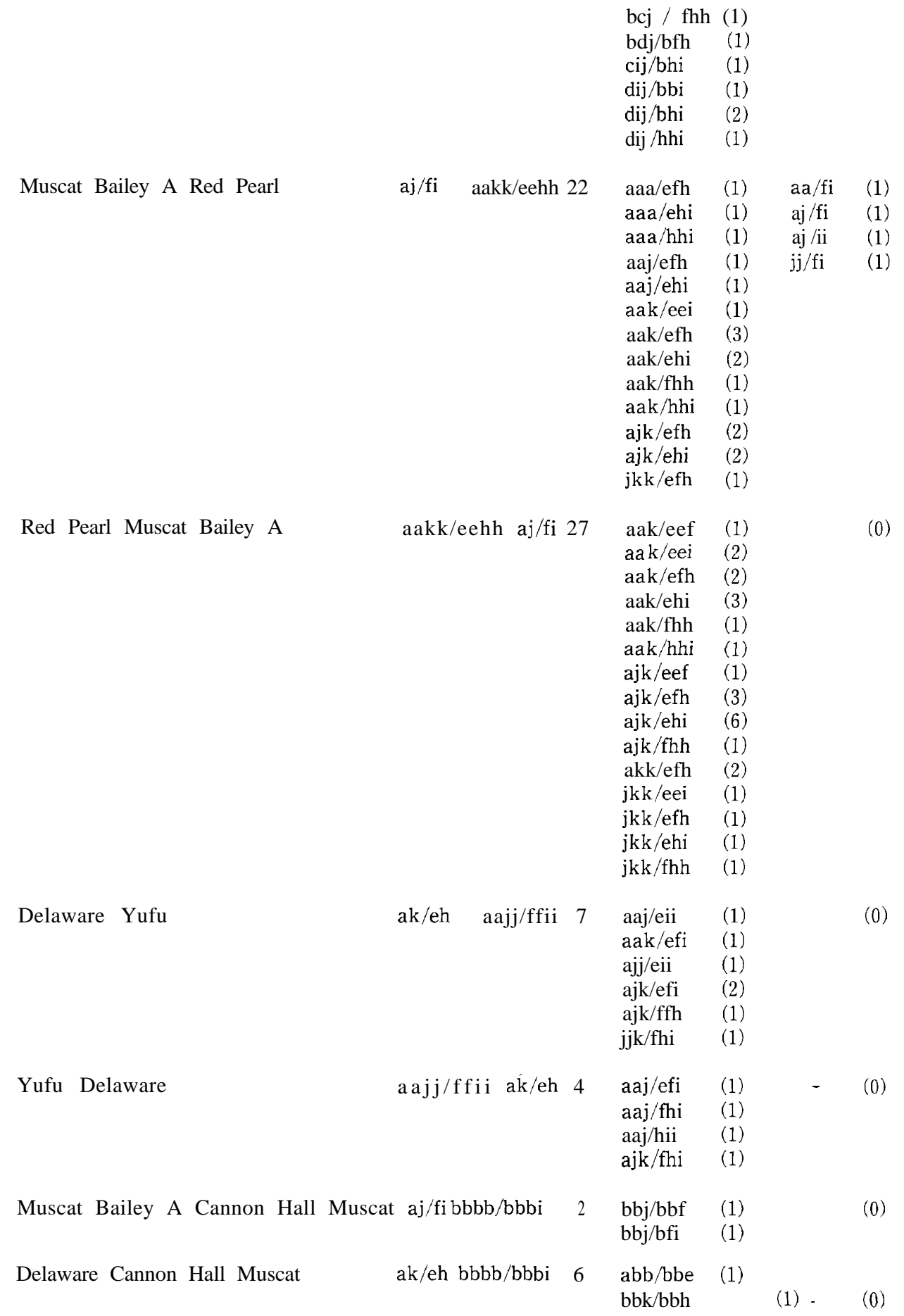


$\mathrm{bbk} / \mathrm{bhi}$

(4)

\begin{tabular}{|c|c|c|c|c|c|c|c|c|}
\hline Delaware & Kyoho & & ak/eh bcdi/bbhh & 1 & $\mathrm{abc} / \mathrm{bbe}$ & (1) & - & $(0)$ \\
\hline Muscat of & Alexandria & Kyoho & $\mathrm{bb} / \mathrm{bi}$ bcdi/bbhh & 1 & $\begin{array}{l}\mathrm{bbc} / \mathrm{bhi} \\
\mathrm{bdi} / \mathrm{bhh}\end{array}$ & $\begin{array}{l}(1) \\
(1)\end{array}$ & - & (0) \\
\hline Muscat of & Alexandria & Red Pearl & $\mathrm{bb} / \mathrm{bi}$ aakk/eehh & 1 & $\mathrm{bkk} / \mathrm{hhi}$ & (1) & - & $(0)$ \\
\hline Rizamat & Yufu & & $\mathrm{dd} / \mathrm{ii} \quad$ aajj/ffii & 2 & adj/iii & (1) & $\mathrm{dd} / \mathrm{ii}$ & (1) \\
\hline Sekirei & Red Pearl & & $\mathrm{bb} / \mathrm{bi}$ aakk/eehh & 4 & $\begin{array}{l}\mathrm{a} a b / \mathrm{bee} \\
\mathrm{aab} / \mathrm{beh} \\
\mathrm{abk} / \mathrm{beh}\end{array}$ & $\begin{array}{l}(1) \\
(1) \\
(2)\end{array}$ & - & $(0)$ \\
\hline Red Pearl & Rizamat & & aakk/eehh bb/hi & 3 & $\begin{array}{l}\text { abk/eei } \\
\text { abk/ehi } \\
\text { abk/hhi }\end{array}$ & $\begin{array}{l}(1) \\
(1) \\
(1)\end{array}$ & & \\
\hline Rea Pearl & Neo Muscat & & aakk/eehh $a b / b b$ & 1 & aak/beh & (1) & - & $(0)$ \\
\hline Yufu Seki & & & $\mathrm{aajj} / \mathrm{ffii} \mathrm{bb} / \mathrm{bi}$ & 1 & $\mathrm{aab} / \mathrm{bii}$ & (1) & - & (0) \\
\hline
\end{tabular}

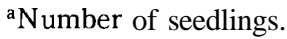

genotype for Gpi -2 respectively. The results of our cytological and morphological studies indicating that both cultivars are periclinal chimera $(2 x-4 x)$ denied these conclusions, since activities of GPI in diploid LI (epidermis) is negligible and since their embryo sacs and pollens originate from tetraploid L. Thus, the genotypes of tetraploid cultivars used as a pistillate or pollen parent were determined as listed in Table 5.

In a large number of the seedlings obtained from crosses between the tetraploid and diploid cultivars, overlap of two or three dimeric allozymes with following subunit

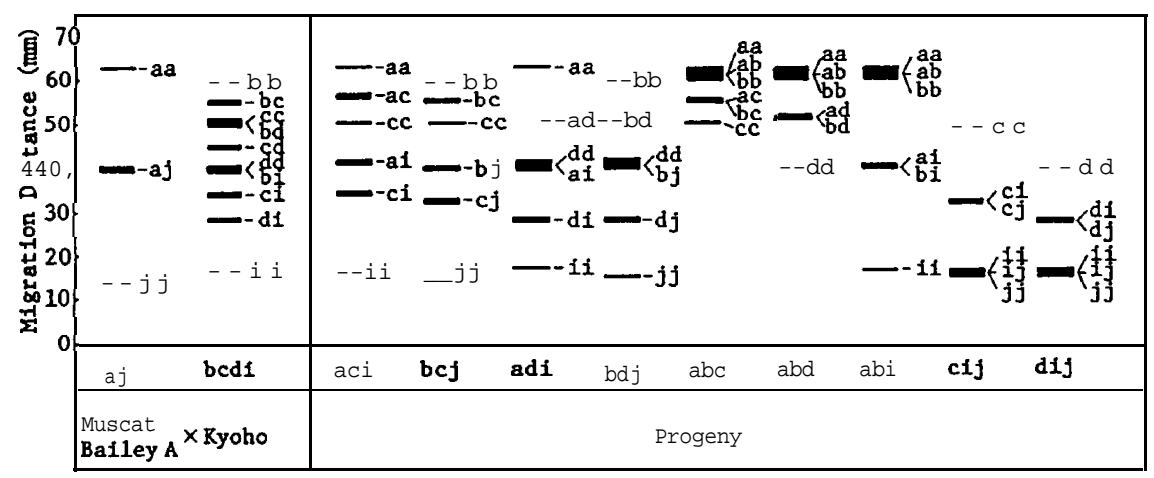

Fig. 7. Schematic illustration of allozymes in 'Muscat Bailey A', 'Kyoho' and their triploid $F_{1}$ progeny for Gpi - 2. Phenotypes and genotypes (below) were shown. Anode is toward the top of the figure. 
association was seen on the gel: aa, ab and bb; ac and bc; ad, bd and cc; dd and ai; dd and aj; dd and bi; dd and bj; ak and bk; ci and cj; di and dj; ii, ij and jj. In the triploid seedlings from 'Muscat Bailey A', 'Kyoho', overlap of dimeric allozyme bands was frequently observed on the gel and resulted in either a three -, five -or six -banded phenotype in spite of their trigenic genotypes (Fig. 7). These results indicate that ploidy level in a given cultivar or seedling is not directly referred from the banding phenotype even if the Gpi-2 genotype consists of more than three different alleles. However, it is also indicated that in these cases the Gpi-2 genotype in a given cultivar or seedling is relatively easily determined if the mobilities of allozyme bands and gene dosage are considered carefully.

Of the 98 seedlings analyzed, 89 exhibiting trisomic gene expression were determined to be triploid hybrids, 3 exhibiting disomic gene expression were determined to be diploids, and 5 were determined to be off-types which were produced by contaminating pollen.

Forth, a similar analysis was carried out to determine the Pgm - 2 genotypes responsible for one-, two- and three -banded pattens which were encountered in the 4 tetraploid cultivars and 98 seedlings obtained from crosses between the tetraploid and diploid cultivars. Because of the monomeric enzyme expression of PGM-2, single-, three- and four-banded patterns observed in tetraploid cultivars must reflect nulliplex, trigenic and tetragenic genotypes respectively, while a two-banded pattern with the same intensity must reflect duplex genotypes and that with very different intensity must reflect simplex genotypes, since duplex produces active allozymes in the ratio 1:1 whereas simplex produces them in the ratio 3:1. The genotypes determined for the 4 tetraploid cultivars used for crossing were listed in Table 5.

The Pgm-2 genotypes of the triploid seedlings obtained from crosses between the tetraploid and diploid cultivars were easily determined, since single - and three-banded patterns reflect nulliplex and trigenic genotypes respectively, and since two two-banded patterns distinguished by relative intensity between the two bands are simplex producing active allozymes in the ratio 2:1. Of the 98 seedlings analyzed, 91 exhibiting trisomic gene expression were determined to be triploid hybrids, 3 exhibiting disomic gene expression were determined to be diploid plants, and 5 without alleles from the pollen parents were determined to be off- types which were produced by contaminating pollen.

On the basis of GPI and PGM analysis, all the genotypes of 98 seedlings obtained from the crosses between the tetraploid and diploid cultivars could be determined for Gpi-2 and Pgm-2 (Table 5). Subsequently, the genotype data confirmed the hybridity and ploidy in the seedlings; i.e., of the 98 seedlings, 92 could be determined to be triploid hybrids and 6 could be determined to be diploid off-types which presumably produced by self -pollination in the diploid pistillate parents. Our cytological data agreed with these conclusions, since chromosome number in the root tip cells is 57 in the 92 triploid hybrids and 38 in the 6 diploid seedlings. 


\section{DISCUSSION}

\section{Stability of GPI and PGM isozymes}

In recent years, considerable overlap of gametophytic and sporophytic gene expression has been demonstrated by electrophoretic analysis of isozymes in several species (Tanksley et al., 1981; Gorla et al., 1986; Rajora and Zsuffa, 1986; Weeden, 1986; Pedersen et al., 1987). Pedersen et al. (1987) indicated from the results of electrophoresis in barley that 30 out of 50 isozymes including those of GPI and PGM are expressed in both pollen and sporophyte. The extensive overlap of gene expression between various sporophytica tissues in plant also has been demonstrated by electrophoretic analysis of isozymes (Vodkin and Scandalios, 1979; Pedersen and Simonsen, 1987). This situation is quite similar in grape species and cultivars since GPI and PGM isozymes were expressed in the various sporophytic tissues, pollen and endosperms analyzed.

In zymograms of GPI, appearance of ghost bands representing degradation products of the primary allozymes is in accordance with the report that ghost bands tend to be faint, develop more slowly, and typically covary in tandem with and in close proximity of their associated primary bands (Kephart, 1990). Kephart (1990) stated that these secondary bands may result from technical aspects, old tissues, or overheating of gels during runs. In GPI of grape, the fact that development of the ghost bands increased with tissue age indicates that not only technical aspects but physiological conditions of tissues in situ also may result in the development of them, although this mechanism is not known at present.

\section{Allozyme Variation}

Among the food crops analyzed electrophoretically, Vitis displays high level of allozyme variation both within germ plasm and among cultivars (Weeden, 1989). The presence of high level of allozyme variation in Vitis may be very useful for the identification of grape cultivars. Stavrakakis and Loukas (1983) studied pollen isozyme banding patterns in 37 grape cultivars ( $V$.vinifera) and found that 11 out of 13 enzyme systems showed different banding patterns and that all cultivars could be identified electrophoretically if more than 2 enzyme systems were combined. Benin et al. (1988) analyzed leaf isozymes of $40 \mathrm{~V}$.vinifera cultivars using 3 enzyme systems and found that combination of 31 variable bands out of 39 bands detected allowed to characterize each cultivar. Although these isozyme analysis were successful for identification of $\mathbf{V}$. vinifera cultivars, the number of cultivars analyzed was too small to conclude that they were very useful for identification of many grape cultivars. In addition, peroxidase and esterase analyzed in these studies are highly variable enzyme systems but are considered to be highly tissue -specific, or under environmental or developmental control as those reported in other many plants (Gottlieb, 1981; Pedersen et al., 1987). Parfitt and Arulsekar (1989) analyzed leaf isozymes of 145 grape cultivars (V. vinifera and Vitis spp.) and found that they could be separated into 52 groups using stable enzyme systems (GPI and PGM). They concluded that unique isozyme identities can not be assigned to many of the cultivars using only GPI and PGM, although the cultivars having different GPI or PGM patterns can be shown to be genetically different cultivars. Our results of GPI and PGM isozyme analysis support their conclusion, 
although we found higher allozyme polymorphism than that reported by them. This indicates that further identification of cultivars due to GPI and PGM isozyme analysis may be possible.

Examination of the Gpi-2 and Pgm -2 data collected in this investigation on the genus Vitis reveals that East Asian, European, and North American species exhibit the great intercontinental divergence. This indicates that, in spite of the cross compatibility between these species, a great deal of genetic divergence has occurred during allopatric speciation as has been suggested in genera with extant species in mesic temperate refugia in eastern North America, East Asia, and southerastern Europe or western Asia (Parks and Wendel, 1990; Hoey and Parks, 1991). The higher level of allelic diversity at the two loci in American hybrids than in $V$. vinifera reflects introgression of genes from American species to $V$. vinifera since the $1850 \mathrm{c}$ to breed for cold tolerance, disease resistance, and Phylloxera and nematoda resistance (Snyder, 1937; Einset and Pratt, 1975).

\section{Ploidy and hybridity confirmation}

The stability of isozyme number and very high levels of allozyme polymorphism in GPI and PGM of grape allow the determination of the ploidy levels inferred by the number and relative intensity of allozyme bands expressed in these highly conserved enzyme systems in which the variations have been defined genetically. Triploid individuals and endosperms are easily identified by their zymograms of GPI and PGM when their genotypes for Gpi -2 and Pgm - 2 are simplex or trigenic. Tetraploid individuals also are easily identified when their genotypes for Gpi-2 and Pgm -2 are simplex, trigenic or tetragenic. When the genotypes of tetraploid individuals for Gpi-2 are duplex, comparison of banding patterns between the sporophytic tissue and the pollen make it possible to identify them to be tetraploid because of the consistent occurrence of heterodimer band. Problem in identification of ploidy level arises when the individuals or endosperms possess nulliplex genotypes for both Gpi-2 and Pgm-2 or when the individuals possess duplex genotypes for Pgm-2 and nulliplex ones for Gpi-2. High heterozygosity at Gpi-2 and Pgm -2 in diploid cultivars analyzed, however, indicates that these combinations of genotypes for Gpi-2 and Pgm -2 are of infrequent occurrence. Therefore, ploidy levels of most grapes, which are usually either diploid, triploid or tetraploid, may be ascertained by banding phenotypes of the two isozymes, GPI-2 and PGM-2.

Of the 92 seedlings from the 15 crosses, 6 had unexpected disomic genotypes which could be explained by accidental self-pollination in the diploid pistillate parents. Of the 6 seedlings, 5 were derived from 2 crosses in which 'Muscat Bailey A' was used as a pistillate parent, and one was derived from 'Rizamat' 'Yufu'. This suggests either that self -pollination had occurred within the buds of 'Muscat Bailey A' and 'Rizamat' before or when emasculation was carried out, or that outcross due to wind- pollination had occurred in the emasculated buds when hand-pollination was carried out. In addition to these reproductive behaviors, the considerable high ratio of $6.5 \%$ contamination may be due to the facts that establishement of plants through embryo culture was easy in normally developed diploid embryos but was considerably difficult in abortive triploid embryos from crosses between diploid and tetraploid cultivars. In triploid grape breeding, therefore, GPI and PGM isozymes exhibiting high levels of allozyme 
polymorphism are very useful for confirmation of hybridity and exclusion of unexpected plants.

\section{Conclusion}

The present analysis has established two marker genes Gpi-2 and Pgm-2 for the confirmation of hybridity and ploidy in grape. The very high polymorphism observed in Gpi-2 and Pgm -2 provides a sound base not only for breeding grape but also for analyzing phylogenetic relationships among Vitis species and cultivars.

\section{REFERENCES}

Arus, P. and T. J. Orton 1984 Inheritance patterns and linkage relationships of eight genes of celery. J.Hered, 75: 11-14

Baritt, B. h. and Einset 1969 The inheritance of three major fruit colors in grapes. J. Amer. Soc. Hort. Sci., 94: 87-89

Benin, M., J. Gasques, A. Mahfoudi and R.Bessis 1988 Caracterisation biochimique des cepages de Vitis vinifera L. par electrophorese d'isoenzymes foliarires: Essai de classification des varietes. Vitis, 27: 157-172

Chaparro, J. X., R. G. Goldy, B. D. Mowrey and D. J. Werner 1989 Identification of Vitis vinifera L. Muscadinia rotundifolia small hybrids by starch gel electrophoresis. HostScience, 24: 128130

Chevreau, E. and F. Laurens 1987 The pattern of inheritance in apple (Malus domestica Borkh.): further results from leaf isozyme analysis. Theor. Appl. Genet., 75: 90-95

Durham, R. E., G. A. Moore, D. J. Gray and J. A. Mortensesn 1989 The use of leaf GPI and IDH isozymes to examine the origin of polyembryony in cultured ovules of seedless grape. Plant Cell Reports, 7: 669-672

Dyer, A. F. 1963 The use of lacto-propionic orcein in rapid squash methods for charomosome preparations. Stain Technology, 38: 85-90

Einset, J. and C.Pratt 1975 Grapes. In: Janick J, Moore JN (eds) Advances in fruit breeding. Purdue Univ. Press, West Lafayette, Indiana, pp 130-153

Goldring, A., D. Zamir and C.Degani 1985 Duplicated phosphoglucose isomerase genes in avocado. Theor. Appl. Genet., 71: 491-494

Goldy, R., R. Emershad, D. Ramming and J. Chaparro 1988 Embryo culture as a means of introgreesing seedlessness from Vitis vinifera to $V$. rotundifolia. HortScience, 23: 886-889

Goldy, R. G., D. W. Ramming, R. L. Emershad and J. X. Chaparro 1989 Increasing production of Vitis vinifera $V$. rotundifolia hybrids through embryo rescue. HortScience, 24: 820-822

Gorla, M. S., C. Frova, G. Binelli and E. Ottaviano 1986 The extent of gametophytic-sporophytic gene expression in maize. Theor. Apple. Genet., 72: 42-47

Gottieb, L. D. 1981 Electrophoretic evidence and plnat populations. Prog. Phytochem., 7: l-46

Gottieb, L. D. 1982 Conservation and duplication of isozymes in plants. Science, 216: 373-380

Gray, D. J., J. A. Mortensen and C. M. Benton 1990 Ovule culture to obtain progeny from hybrid seedless bunch grapes. J.Ame.Soc.Hort.Sci., 115: 1019-1024

Hoey, M. T. and C. R. Parks 1991 Isozyme divergence between eastern Asian, North American, and Turkish species of Liquidumber (Hamamelidaceae). Amer. J. Bot., 78: 938-947

Kahler, A. L. and C. L. Lay 1985 Genetics of electrophoretic variants in the annual sunflower. $J$. Hered., 76: 335-340

Kephart, S. R. 1990 Starch gel electrophoresis of plant isozymes: a comparative analysis of techniques. Amer. J. Bot., 77: 693-712

Loukas, M., M. N. Stavrakakis and C. B. Krimbas 1983 Inheritance of polymorphic isoenzymes in grape cultivars. J.Hered., 74: 181-183

Mortensen, J. A. 1968 The inheritance of resistance to Pierce's disease in Vitis, Proc. Amer. Soc. 
Hort. Sci., 92: 331-337

Murashige, T. and F.Skoog 1962 A revised medium for rapid growth and bio - assays with tobacco tissue cultures. Phisiol. Plant, 15: 473-497

Olmo, L. P. 1976 Grapes. In: Simmonds NW (ED) Evolution of crop plants. Longman, London New York, pp 294-298

Parfitt, D. E. and S. Arulsekar 1989 Inheritance and isozyme diversity for GP-I and PGM among grape cultivars. J. Amer. Soc. Hort. Sci., 114: 486-491

Parfitt, D. E., S. Arulsekar and D. W. Ramming 1985 Identification of plum peach hybrids by isoenzyme analysis. HortScience, 20: 246-248

Parks, C. R. and J. F. Wendel 1990 Molecular divergence between Asian and North American species of Liriodendron (Magnoliaceae) with implications for interpretation of fossil floras. Amer. J. Bot., 77: 1243-1256

Pedersen, S. and V.Simonsen 1987 Tissue specific and developmental expression of isozymes in barley (Hordeum vulgare L.). Hereditas, 106: 59-66

Pedersen, S., V. Simmonsen and V.Loeschcke 1987 Overlap of gemetophytic and sporophytic gene expression in barley. Theor. Appl. Genet., 75: 200-206

Rajora, 0. P. and L. Zsuffa 1986 Sporophytic and gametophytic gene expression in Populus deltoides Marsh., P. nigra L., and P. maximowiczii Henry. Can. J. Genet. Cytol., 28: 476-482

Schwennesen, J., E. A. Mielke and W. H. Wolfe 1982 Identification of seedless table grape cultivars and a bud sport with berry isozymes. HortScience, 17: 366-368

Snyder, E. 1937 Grape development and improvement. USDA Yearbook of Agriculture 1937: 631 664

Stavrakakis, M. and M. Loukas 1983 The between - and within-grape - cultivars genetic variation. Sci. Hortic., 19: 321-334

Stout, A. B. 1939 Progress in breeding for seedless grapes. Proc. Amer. Soc. Hort. Sci., 37: 627-629

Subden, R. E., A.Krizus, S. C. Lougheed and K.Carey 1987' Isozyme characterization of Vitis species and some cultivars. Amer. J.Enol.Vitic., 38: 176-181

Suiter, K. A. 1988 Genetics of allozyme variation in Gossypium arboreum L. and Gossypium herbaceum L. (Malvaceae).Ther. Appl. Genet., 75: 259-271

Tanksley, S. D., D.Zamir and C.M.Rick 1981 Evidence for extensive overlap of sporophytic and gametophytic gene expression in Lycopersicon esculentum. Science., 213: 453-455

Torres, A. M., R. K. Soost and U.Diedenhofen 1978 Leaf isozymes as genetic markers in citrus. Amer. J. Bot., 65: 869-881

Vodkin, L. 0. and J. G. Scandalios 1979 Developmental expression of genetically defined peptidases in maize. Plant Physiol., 63: 1198-1204

Walters, T.W., U. Posluszny and P. G. Kevan 1989 Isozyme analysis of the grape (Vitis). I. A practical solution. Can. J. Bot., 67: 2894-2899

Webb, E. C. 1984 Enzyme nomenclature. International Union of Biochemistry. Nomenclature Committee. Academic Press. Orlando, Fla, P 646

Weeden, N. F. 1986 Identificaiton of duplicate loci and evidence for post meiotic gene expression in pollen. In: Mulcahy D, Mulcahy GB, Ottaviano E (eds) Biotechnology and ecology of pollen. Springer-Verlag, New York

Weeden, N. F. 1989 Application of isozymes in plant breeding. In: Janick J (ed) Plant breeding reviews. Timber Press, Portland, Ore, pp $11-54$

Weeden, N. F. and L. D. Gottieb 1979 Distinguishing allozymes and isozymes of phosphoglucoisomerases by electrophoretic comparisons of pollen and somatic tissues. Biochem. Genet., 17: 287-296

Weeden, N. F. and J. F. Wendel 1989 Genetics of plant isozymes. In: Soltis DE and Soltis PS (eds) Isozymes in plant biology. Dioscorides Press, Porland, Ore, pp 46-72

Weeden, N. F., B. I., Reisch and M. E. Martens 1988 Genetic analysis of isozyme polymorphism in grape. J.Amer. Soc. Hort. Sci., 113: 765-769

Wendel, J. F. and C. R. Parks 1982 Genetic control of isozyme variation in Camellia japonica L. J. Hered., 73: 197-204 
Wendel, J. F. and C. R. Parks 1983 Cultivar identification in Camellia japonica L. using allozyme polymorphisms. J. Amer. Soc. Hort. Sci., 108: 290-295

Wolfe, W. H. 1976 Identification of grape varieties by isozyme banding patterns. Am. J. Enol.

Vitic., 27: 68-73 